\title{
Standard DAPI karyotype of the common shrew Sorex araneus L. (Soricidae, Eulipotyphla)
}

\author{
Julia M. Minina*, Pavel M. Borodin, Jeremy B. Searle, Vitaly T. Volobouev \\ \& Natalia S. Zhdanova
}

\begin{abstract}
A DAPI-banding technique was used to characterise the individual patterns of each chromosome of the Novosibirsk race of the common shrew (Sorex araneus) which has become a model for comparative gene mapping. In order to outline the main identifying characteristics of the individual chromosomes and to make comparisons to previously published G-banded karyotypes, we analysed DAPIbanded chromosomes with different degrees of condensation. On the basis of this analysis we constructed idiograms of chromosomes at a 300 band stage of resolution.
\end{abstract}

KEY WORDS: Sorex araneus, common shrew, chromosomes, DAPI banding.

\begin{abstract}
Julia M. Minina [minina jul@mail.ru], Pavel M. Borodin, and Natalia S. Zhdanova [zhdanova@bionet.nsc.ru], Institute of Cytology and Genetics, Siberian Branch of the Russian Academy of Sciences, Novosibirsk 630090, Russia; Pavel M. Borodin [borodin@bionet.nsc.ru], Department of Cytology and Genetics, University of Novosibirsk, Novosibirsk 630090, Russia; Jeremy B. Searle [jbs3@york.ac.uk], Department of Biology, University of York, York YO10 5YW, United Kingdom; Vitaly T. Volobouev, Muséum National d'Histoire Naturelle, Laboratoire de Zoologie, Mammifères et Oiseaux, rue Buffon 55, 75005 Paris Cedex 05, France.
\end{abstract}

\section{Стандартный DAPI-окрашенный кариотип обыкновенной бурозубки Sorex araneus L. (Soricidae, Eulipotyphla)}

\begin{abstract}
Ю.М. Минина, П.М. Бородин, Дж.Б. Сирл, В.Т. Волобуев, Н.С. Жданова
РЕЗЮМЕ. С использованием дифференциального окрашивания с помощью DAPI проанализированы и охарактеризованы индивидуальные хромосомы новосибирской хромосомной расы обыкновенной бурозубки (Sorex araneus). Для того чтобы выявить основные идентифицирующие характеристики каждой хромосомы и сравнить их с кариотипами, описанными ранее с использованием дифференциального G-окрашивания, мы анализировали хромосомы разной степени конденсации хроматина. На основе этого анализа представлены идиограммы всех хромосом на уровне разрешения в 300 бэндов.
\end{abstract}

КЛЮЧЕВЫЕ СЛОВА: Sorex araneus, обыкновенная бурозубка, хромосомы, DАРІ бэндинг.

\section{Introduction}

In terms of karyological evolution the common shrew Sorex araneus is interesting and well studied (for review, see Wójcik et al., 2002). This species varies both in chromosome number and morphology reflecting the multiple occurrences of Robertsonian fusions and wholearm reciprocal translocations. In particular, more than 70 different chromosome races have been identified, each characterised by a particular complement of biarmed autosomes (Wójcik et al., 2003).

The first banded karyotypes of $S$. araneus were produced after Q-banding by Halkka et al. (1974) and G-banding by Král \& Radjabli (1974). This was followed by a G-banded karyotype made by Olert \& Schmid (1978). But a truly standard nomenclature of G-banded chromosomes of $S$. araneus was not developed until

* Corresponding author
1991 by the International Sorex araneus Cytogenetics Committee, ISACC (Searle et al., 1991).

The Novosibirsk chromosome race of common shrew, which was one of the first races described (Král \& Radjabli, 1974), recently has become a model for comparative gene mapping, with extensive use of FISH with specific DNA probes (Dixkens et al., 1998; Zhdanova et al., 2005). The application of G-banding to FISH studies is time-consuming and is often unreliable. Currently it is being replaced by banding with 4',6diamidino-2-phenylindole (DAPI) (Schweizer, 1980; Boyle et al., 1992; Breen et al., 1999). The major advantage of DAPI banding is that it allows simultaneous visualisation of a banding pattern at the same time as FISH signals (Langford et al., 1996). The human genome mapping project as well as gene mapping projects in other mammalian species use DAPI banding for whole chromosome and chromosome band identification (Heng \& Tsui, 1994; Muller et al., 1997). 


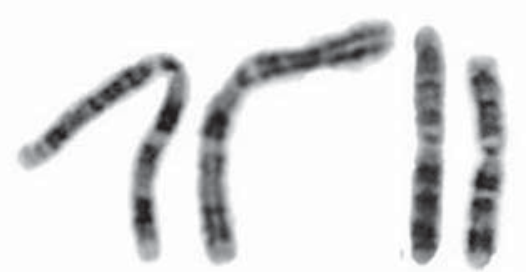

bc

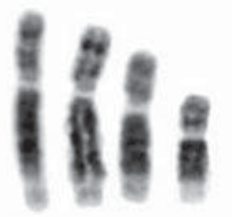

go

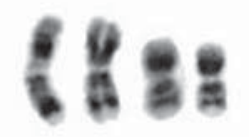

$m p$

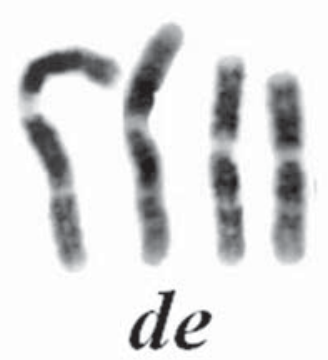

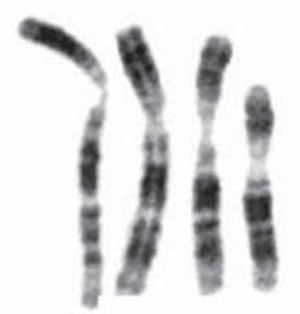

af

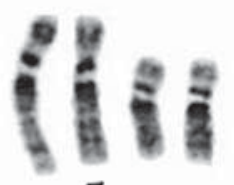

hn
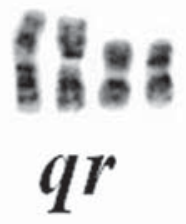

28

$t u$

Figure 1. Inverted DAPI-banded chromosomes of Sorex araneus (Novosibirsk race) at different stages of condensation. Letters and combinations of letters denote chromosomal arms and chromosomes, correspondingly.

In this paper we present for the first time a detailed DAPI-banded karyotype and idiogram of the Novosibirsk race of the common shrew. For the purposes of continuity, the layout of the karyotype and the nomenclature of the DAPI-banded idiogram retain maximum identity with the existing G-banded nomenclature suggested by ISACC (Searle et al., 1991).

\section{Material and methods}

Primary fibroblasts were obtained from pieces of intercostal muscle of two wild-caught $S$. araneus, collected near Novosibirsk (Russia). The cell culture was treated with $10-15 \mu \mathrm{g} / \mathrm{ml}$ ethidium bromide and with 3 $\mu \mathrm{g} / \mathrm{ml}$ colchicine at $2-3 \mathrm{~h}$ and $30 \mathrm{~min}$ before fixation, respectively. Hypotonic treatment was performed with $0.075 \mathrm{M} \mathrm{KCl}$ for $30 \mathrm{~min}$ at $37^{\circ} \mathrm{C}$ and followed by prefixation. The cell suspension was fixed with a mixture of ethanol/acetic acid (3:1) and dropped on to cooled slides which were then dried for $2 \mathrm{~h}$ at $65^{\circ} \mathrm{C}$ and stained for $4 \mathrm{~min}$ with a $1 \mu \mathrm{g} / \mathrm{ml}$ solution of DAPI in 2xSSC. Then slides were washed in deionised water and dried at room temperature. Fluorescence signals were visualized under an Axioskop 2 epifluorescence microscope (Carl Zeiss, Germany) equipped with a CCD camera (CV M300, JAI Corporation, Japan), 


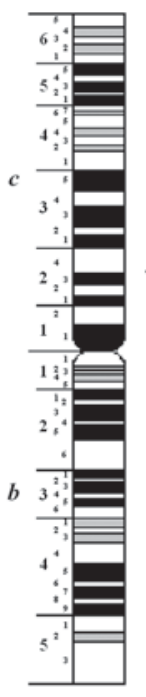

bc

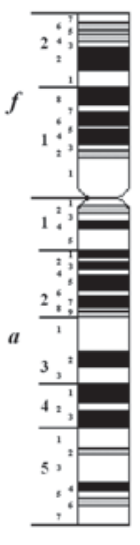

af

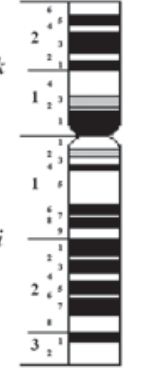

$i k$

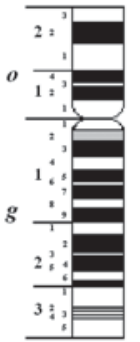

go

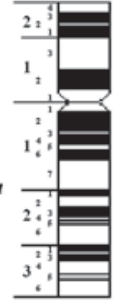

hn

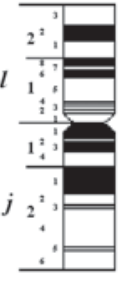

jl

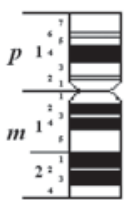

$m p$

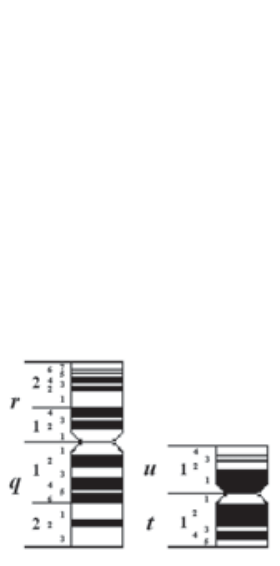

tu

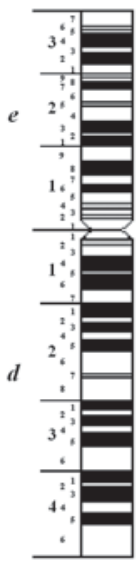

de

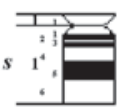

$s$

Figure 2. Inverted DAPI-banded idiogram of Sorex araneus (Novosibirsk race).

CHROMA filter set and ISIS4 image-processing package (MetaSystemsGroup, Inc., USA).

All chromosome pairs were identified in each of 30 mid-metaphase spreads. Karyotypes were produced from the spreads and used to derive a DAPI-band idiogram.

\section{Results and discussion}

In order to determine the main identifying characteristics of the individual chromosomes of $S$. araneus for comparison with previously published karyotypes, we included in our analysis a detailed study of chromosomes at different degrees of condensation (Fig. 1). On the basis of this study we propose a standard nomenclature for DAPI-stained chromosomes of $S$. araneus, which is suitable for a unified description of chromosome races and individual variants. We also constructed an idiogram for every chromosome (Fig. 2). In this description we follow the rules for nomenclature suggested by ISACC (Searle et al., 1991) and ISCN (1995). For continuity, wherever possible, the precise nomenclature of each schematic chromosome, including landmark bands, was retained as that proposed by ISACC (Searle et al., 1991). The main bands revealed by DAPIstaining are rather similar to those detected by G-banding (Searle et al., 1991).

Our study offers a 310-band differentially shaded idiogram. This idiogram provides a framework upon which the physical genome map of the common shrew will be constructed.

ACKNOWLEDGMENTS. This work was supported by research grants from INTAS (grant No. 03-51-4030) and the Russian Foundation for Basic Research (grant No. 07-0400119a).

\section{References}

Boyle A.L., Feltquite D.M., Dracopoli N.C., Housman D.E. \& Ward D.C. 1992. Rapid physical mapping of cloned DNA on banded mouse chromosomes by fluorescence in situ hybridisation // Genomics. Vol.12. P.106-115.

Breen M., Bullerdiek J. \& Langford C.F. 1999. The DAPI banded karyotype of the domestic dog (Canis familiaris) generated using chromosome-specific paint probes // Chromosome Research. Vol.7. P.401-406.

Dixkens C., Klett C., Bruch J., Kollak A., Serov O.L., Zhdanova N., Vogel W. \& Hameister H. 1998. ZOO-FISH analysis in insectivores: "Evolution extols the virtue of the status quo" // Cytogenetics and Cell Genetics. Vol.80. P.61-67.

Halkka L., Halkka O., Skarén U. \& Söderlund V. 1974. Chromosome banding pattern in a polymorphic population of Sorex araneus in northeastern Finland // Hereditas. Vol. 76. P.305-314.

Heng H.H. \& Tsui L.C. 1994. FISH detection on DAPIbanded chromosomes // Methods in Molecular Biology. Vol.33. P.35-49.

ISCN. 1995. An International System for Human Cytogenetic Nomenclature. Mitelman F. (ed.). Basel: S. Karger.

Král B. \& Radjabli S.I. 1974. Banding patterns and Robertsonian fusion in the Western Siberian population of Sorex araneus (Insectivora, Soricidae) // Zoologicke Listy. Vol.25. P.327-334.

Langford C.F., Fischer P.E., Binns M.M., Holmes N.G. \& Carter N.P. 1996. Chromosome-specific paints from a high-resolution flow-karyotype of the dog // Chromosome Research. Vol.4. P.115-123.

Muller S., Rocchi M., Ferguson-Smith M.A. \& Wienberg J. 1997. Toward a multicolor chromosome bar code for the entire human karyotype by fluorescence in situ hybridisation // Humangenetik. Vol.100. P.271-278. 
Olert J. \& Schmid M. 1978. Comparative analysis of karyotypes in European shrew species. I. The sibling species Sorex araneus and S. gemellus: Q-bands, G-bands, and position of NORs // Cytogenetics and Cell Genetics. Vol.20. P.308-322.

Searle J.B., Fedyk S., Fredga K., Hausser J. \& Volobouev V.T. 1991. Nomenclature for the chromosomes of the common shrew (Sorex araneus) // Mémoires de la Société Vaudoise des Sciences Naturelles. Vol.19. P.1322.

Schweizer D. 1980. Simultaneous fluorescent staining and specific heterochromatic regions (DA-DAPI bands) in human chromosomes // Cytogenetics and Cell Genetics. Vol.27. P.190-193.
Wójcik J.M., Ratkiewicz M. \& Searle J.B. 2002. Evolution of the common shrew Sorex araneus: chromosome and molecular aspects // Acta Theriologica. Vol.47. Suppl.1. P.139-167.

Wójcik J.M., Borodin P.M., Fedyk S., Fredga K, Hausser J., Mishta A., Orlov V.N., Searle J.B., Volobouev V.T. \& Zima J. 2003. The list of the chromosome race of the common shrew Sorex araneus (updated 2002) // Mammalia. Vol.67. P.169-178.

Zhdanova N.S., Karamisheva T.V., Minina J., Astakhova N.M., Lansdorp P., Kammori M., Rubtsov N.B. \& Searle J.B. 2005. Unusual distribution pattern of telomeric repeats in the shrews Sorex araneus and Sorex granarius // Chromosome Research. Vol.13. P.617-625. 